\title{
Renewable energy strategy in Hungary
}

\author{
Imre Török \\ University of Debrecen Faculty of Agricultural and Food Sciences and Environmental Management, \\ Institute for Land Utilisation, Technology and Regional Development, Debrecen \\ torok.imre@agr.unideb.hu
}

\section{SUMMARY}

The price of energy determinates our daily life. It is very necessary that we make energy strategy such as effective in everyday life, furthermore appoint a predictable development path. In these energy strategies the renewable energy and the energy efficiency is highlighted. This article describes about relevant pledges from recent years and possible improvements.

Keywords: energy efficiency, renewable energy, operation, primary energy

\section{ÖSSZEFOGLALÁS}

Az energia árak meghatározzák mindennapjainkat. Fontos, hogy olyan energia stratégiáink szülessenek, melyek nem csak a jelen hétköznapokban hatékonyak, de kiszámitható fejlödési pályát jelöl ki. Ezekben az energia stratégiákban kiemelt szerepet kap a megújuló energia és az energiaracionalizálás. Jelen cikkben az elmúlt pár év idevonatkozó vállalásairól, és a lehetséges fejlesztésekröl értekezem.

Kulcsszavak: energiahatékonyság, megújuló energia, üzemeltetés, primer energia

\section{INTRODUCTION}

Some details and new goals can be found regarding the new energy policy changes every day. It is also important to deal with this issue, since the energy price determinates not only our spending, but it affects university education, research and innovation developments as well. The theme is actual: firstly the overhead reduction is performed in second level in our country, secondly the Visegrad Group meeting was hold recently, where the energy policy was also a featured topic.

It was agreed between the leaders of countries that connection of the Hungarian and Slovak gas pipelines in January 2015, which allows the transfer of five billion cubic meters of gas. Through this development the region's energy security is also stepped up. Gas pipelines and their track have been a strategic key element always and it will be more important in the future. Key outcome of this meeting was that members preference the nuclear power and the shale gas extraction in future. Important to note in this regard, that exhibitions related to shale gas has evolved - said Behrooz Abdolvand, professor of Berlin Free University. "It should be considered, Europe is densely populated area, where consequences of shale gas extraction referring to the measured environmental cannot be ignored. Arriving to this point we need to ask, who will handle the consequences of fracking in these countries? At the latest at this point Germany, as the most important economic partner, will also have a word to this topic" - foreshadows the energy policy research professor.

Thus, even in the EU member states are already quite a few completely new turn of energy policies and there are specific goals, meanwhile the trend is in progress in Hungary. The other preferred option is the use of nuclear energy, which is also a less popular line in Western Europe, as the planned shutdown of nuclear power shows in Germany: eight power stations have been already linked out.

\section{MATERIAL AND METHODS}

There are several environmental energy recovery systems, whose utilization could be very good in Hungary. This article also points to two areas: one of them is the solar energy, the other is the possibility of geothermal energy utilization. Unfortunately, however, these systems are currently spreading in our country they do not really have the room for improvement and it seems that the public funding is not suffice for the future. The scheme has not been so favorable, so we should re-think our renewable energy strategy in order to increase the part of renewable in our energy mix (European Wind Energy Association, 2013).

We could take the example from the often-mentioned Germany, where 80 percent of its energy will derive from renewable sources by 2050 . These change results in Germany are not only political decisions, and not only technical development projects, but they are common trends among industry, academia, politics and civil society. Figure 1 shows the energy consumption by sectors in Hungary. It can be concluded that one of the biggest user is the population. This number means that approximately $400 \mathrm{PJ}$ of energy used by the population, of which $320 \mathrm{PJ}$ are used for air-conditioning and the production of hot water.

This division between the sectors has not changed significantly in the recent years, generally two things come to our mind about the energy uses: one is to increase the energy efficiency, the other is how much it costs. However, it is important also to know what we are able to produce by the energy, what is the energy used for. After all, the energy is only a tool, which should create a product, and if we have any income from it, it would be easier to pay for. So the country would have to produce more products. 
Figure 1: Primary energy consumption by sectors in Hungary (2009)

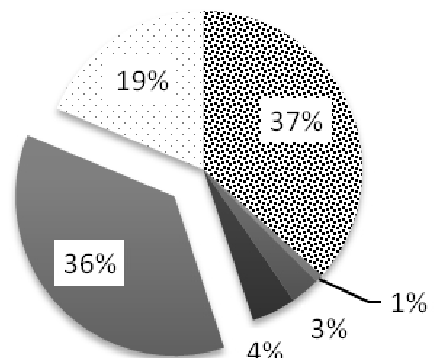

Fi Industry

Building industry

- Agriculture

- Transportation and warehousing

Source: Net1

Considering the source of primary energy consumed in our country were vast majority of natural gas and oil. We need to import the majority of both. The ratios and their changes over the last decades can be monitored in the Figure 2.

Figure 2: Primary energy consumption by source

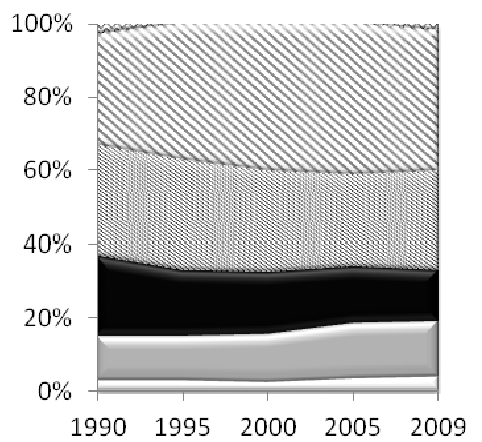

Import of electricity Natural Gas

Oil

Garbon

$\square$ Nuclear Energy

$\sqcup$ Other

Source: Energiaközpont Nonprofit Kft.
So we cannot solve our energy supply based only on our own resources, therefore we have to import it. It would be very obvious, to increase the share of renewables in the energy mix. According to the Renewable Energy Action Plan, renewable energy share will be as in Figure 3.

Figure 3: All renewable energy share in Hungary

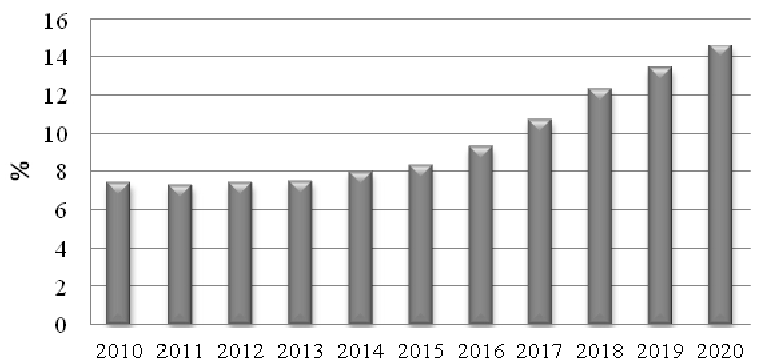

Source: Net2

It is planned to increase the share of environmental energy recovery systems to be $14.6 \%$ in 2020 , at least that's the goal we set out. However, to reach this level, payment scheme and attitude change would be required. These systems could change the direction of selfsufficiency furthermore it could reduce our expenditures. As of now we use a lot of energy for our buildings, it is important to create a good building energy strategy, which will contribute to the modernization. These smaller energy needs should be produced based on renewables, which are favorable opportunities in our country. Such as solar energy, geothermal energy and biomass utilization.

The Hungarian Energy and Utilities Regulatory Agency carried out a study, which studied the EU electricity rates. Figure 4 shows the results of the test. They not only examined the prices, but those components have been analyzed.

Figure 4: Electicity price for consumers in $\mathbf{2 0 1 3}$

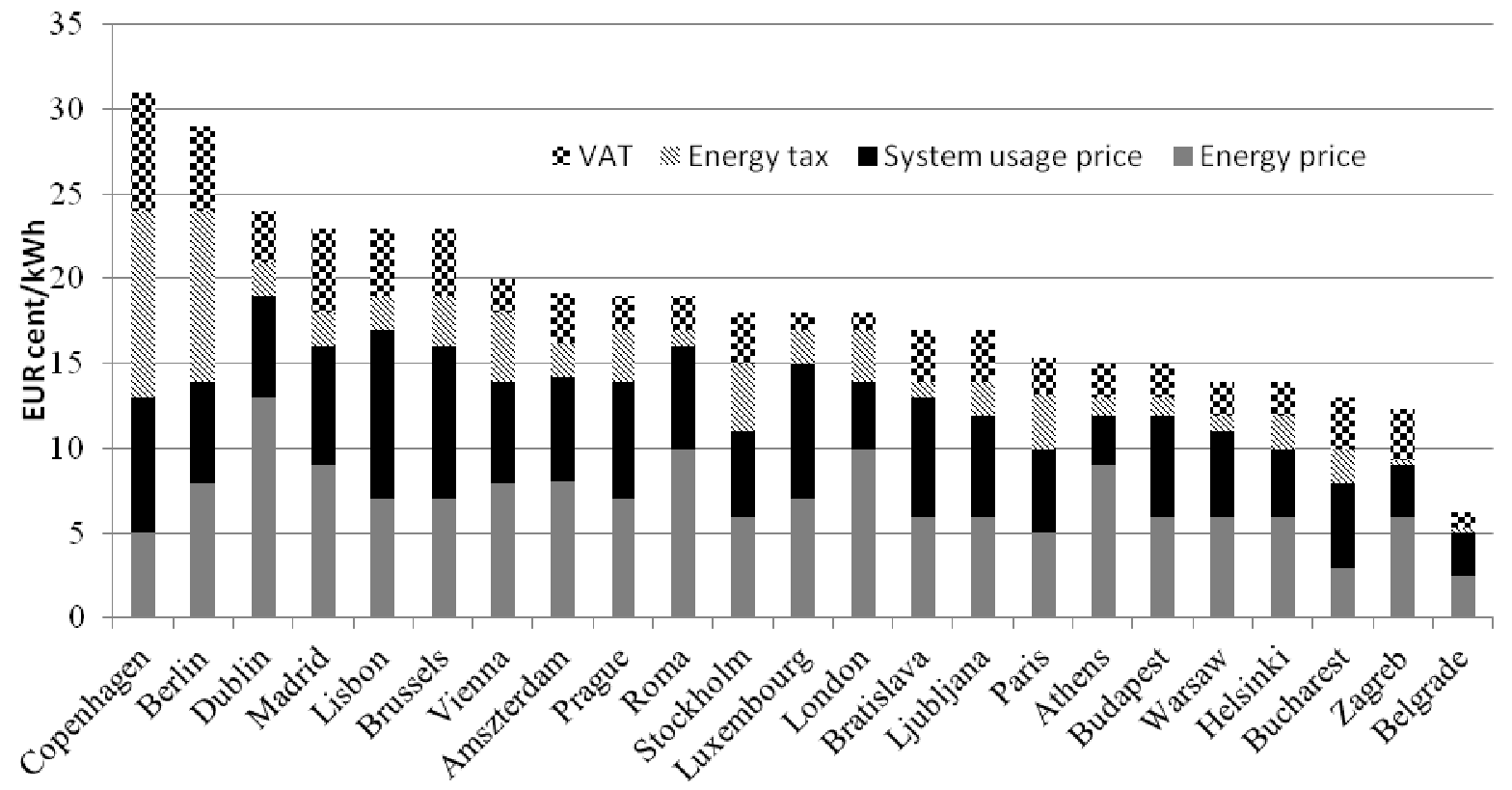

Source: Net1 
We can conclude based on this study, that the Hungarian energy prices are relatively favorable in the region, because there are few countries where the prices are cheaper than here. However, the aspect is not so positive, if we compare income per capita and the ratio of the price of electricity. In this case situation is almost the worst in our country. The survey shows that the only region where the citizens pay more for the electricity is Romania. According to this data - presented by the previously mentioned studies - in Bucharest $8.6 \%$, in Budapest 6.6\% meanwhile in Wien 2.2\%.

The share of renewable energy in final energy consumption was only $6.6 \%$ in 2008 and by 2010 it reached just $7.4 \%$, among the EU countries, ranking Hungary to the lower third. The average of EU27 in 2008 was: $10.3 \%$, and still other similarly developed countries are lagging behind, if we take the example of Bulgaria (9.4\%), Bohemia (7.2\%), Poland (7.9\%), Romania $(20.4 \%)$ or Slovakia, where $8.4 \%$. The difference versus surrounding countries can be partly explained by the better and better utilization of the hydropower potential and indicators of forest cover, on the other hand, however, can be defined by a more effective regulatory system than in Hungary. This indicator should be at least $13 \%$ according to the 2009/28 EC Directive 14 in our country by 2020 . The Directive also contains a schedule estimate, the first step, which has probably come true. In my opinion we are not able to see the huge opportunity and try to develop continuously, rather we are trying to do only the minima and draggle at the end, even so our country has a very good renewables potential too (Net2).

The European Commission adopted an Action Plan, which aims to reduce the energy consumption by $20 \%$ by 2020 . The measures contained in the Action Plan have a clear goal: increase the energy performance of products, buildings and services to increase the energy efficiency, enhancing the efficiency of energy production and distribution. Reduce the impact of transport on energy consumption and to facilitate the financing and implementation of investments in this area. Encourage and strengthen rational behavior regarding energy consumption, and pushing international actions on energy efficiency.
The European Union Action Plan aims to mobilize public opinion, public policy makers and market participants, as well as to remodel the internal energy market in such a way that energy-efficient infrastructure, processes and energy services could provide disposal for the EU citizens at a world class level. The Action Plan aims to control and reduce energy demand, which is planned to be approximately $1.5 \%$ per year in savings by 2020 . The considerable and prolonged energy saving can be reached by developing continuously energy saving technologies, products and services, additionally the thinking and behavior according to energy should be changed in order to consume less at the same standard of living. The action plan would lead to benefits such as enhanced industry competitiveness, increased export opportunities for new technologies, as well as positive effects on employment. Furthermore the savings achieved in addition could compensate investments in innovative technologies (Net3) (Figure 5).

The combined effects of full implementation of the existing and new measures has the potential to generate financial savings of up to $€ 1000$ per household each year; improve Europe's industrial competitiveness; create up to 2 million jobs. Engage with industry and consumer organizations to create the right conditions for better information, communication Bills have to be clear and sent regularly to customers reflecting the real costs, not a forfeit. Set out its approach to smart grids and smart metering in more detail in a Communication in the next months. This will help consumers to know in more detail where he has consumed how much energy. It will be possible to break this information down to specific rooms or even specific machines and appliances.

What is the difference between "Energy Efficiency" and "Energy Savings"? While the two words are often used interchangeably, technically, 'energy efficiency' means using less energy inputs while maintaining an equivalent level of economic activity or service; 'energy saving' is a broader concept that also includes consumption reduction through behavior change or decreased economic activity. Examples of energy savings without efficiency improvements are heating a room less in winter, using the car less, or enabling energy saving modes on a computer (Net5) (Figure 6).

Figure 5: Projection of primary energy use for the EU by 2020

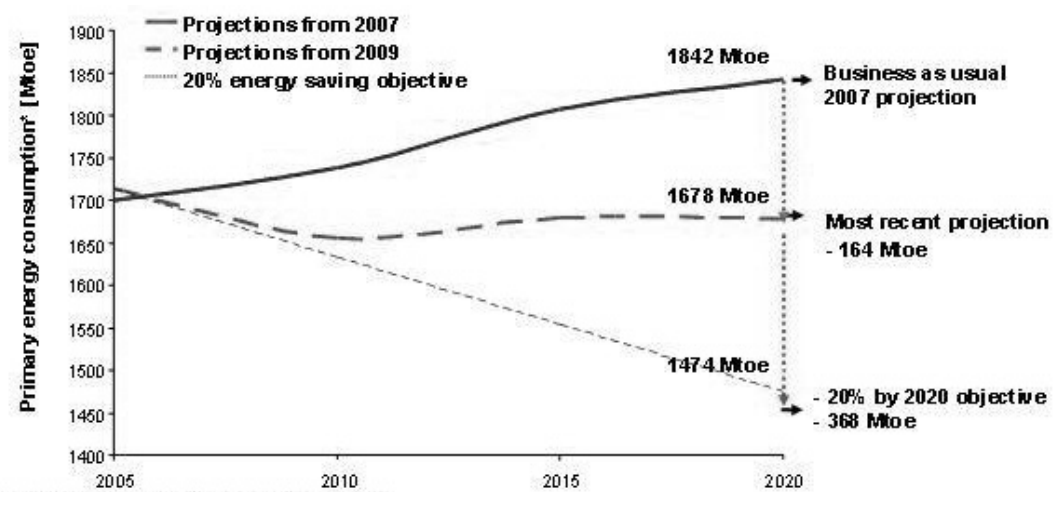

Note: "gross intand consumption minus non-energy uses.

Source: Net4 
Figure 6: Global renewable energy subsidies by source in the New Policies Scenario

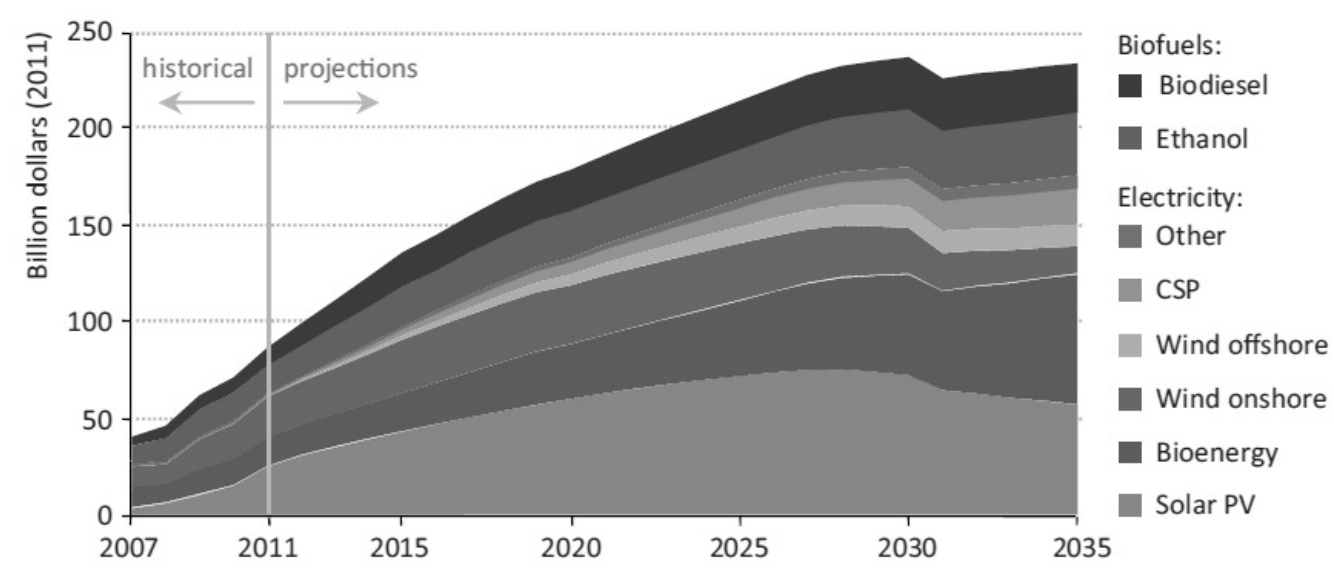

Note: other includes geothermal, marine and small hydro; $\mathrm{CSP}=$ concentrating solar power.

Source: Net6

\section{CONCLUSIONS}

In near future we should not only focus on rationalization and reducing our energy consumption, thereafter we have to elicit this lower level with renewables as much as possible. In our country there is a high environmental energy recovery potential. The expansion of renewable energy systems can help to decentralize our power supply system and it opens up new directions of development such as a smart grid system. Justified on the basis of
Figure 6, that both of the solar and bio-energy will be supported very seriously in the future and these areas of our country will start with very good conditions. In the future those power plants will get high priority which will be able to ensure load distribution. Integrating these systems with the development of smart networks must be ensured, not only to balance the daily consumption curves and conventional production but also uncertainties due to climatic handle, thus local or central energy storage solutions can be developed.

\section{REFERENCES}

European Wind Energy Association (2013): Eastern winds Emerging European wind power markets. February 2013.

Net1: Magyar Energetikai és Közmü-szabályozási Hivatal. A lakossági villamos energia és földgázárak nemzetközi összehasonlító vizsgálata 2013. http://www.mekh.hu/statisztika/energia-statisztika/adatok-es-tablazatok/archiv-dokumentumok.html
Net2: Hungary recovery action plan for renewable energy. 2010.

Net3: Action Plan for Energy Efficiency: Realizing the Potential. 2006.

Net4: EUROSTAT Statics Database.

Net5: The Commission's new Energy Efficiency Plan. 2011.

Net6: IEA World energy outlook. 2012. 